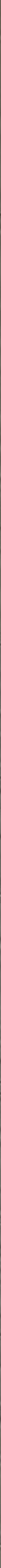


HARVARD UNIVERSITY.

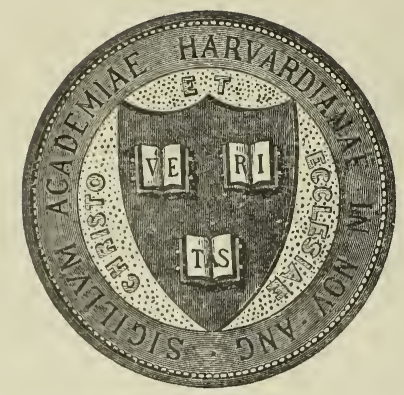

LIBRARY

$$
\text { OF THE }
$$

MUSEUM OF COMPARATIVE ZOÖLOGY 52,475 Exchange.

(1) ctober 3, 1919. 
52,475

\title{
DETERMINING THE AGE OF CATTLE BY THE TEETH
}

\author{
GEORGE W. POPE
}

Quarantine Division

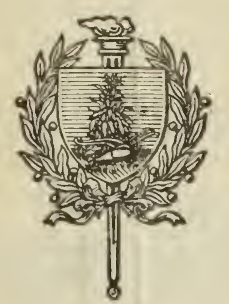

FARMERS’ BULLETIN 1066

UNITED STATES DEPARTMENT OF AGRICULTURE

\section{- Contribution from the Bureau of Animal Industry}

JOHN R. MOHLER, Chief

Washington, D: C.

Show this bulletin to a neighbor. Additional copies may be obtained free from the Division of Publications, United States Department of Agriculture 


\section{PUBLICATIONS OF U. S. DEPARTMENT OF AGRICULTURE RELATING TO CATTLE.}

\section{AVAILABLE FOR FREE DISTRIBUTION BY THE DEPARTMENT.}

Vesicular Stomatitis of Horses and Cattle. (Department Bulletin 662.)

Hemorrhagic Septicemia. (Department Bulletin 674.)

Breeds of Beef Cattle. (Farmers' Bulletin 612.)

The Feeding of Dairy Cows. (Farmer's' Bulletin 743.)

Feeding and Management of Dairy Calves and Young Dairy Stock. (Farmers' Bulletin 777.)

Contagious Abortion of Cattle. (Farmers' Bulletin 790.)

Breeds of Dairy Cattle. (Farmers' Bulletin 893.)

Dehorning and Castrating Cattle. (Farmers' Bulletin 949.)

Cattle Scab. (Farmers' Bulletin 1017.) 


\section{DETERMINING THE AGE OF CATTLE BY THE TEETH.}

THE AGE OF CATTLE can be approximated closely by the 1 appearance, development, and subsequent wear of their second incisor teeth. Cattle have eight incisor teeth, all in the lower jaw. In the calf at birth two or more of the temporary or first incisor teeth are present. With the first month the entire eight incisors have appeared.

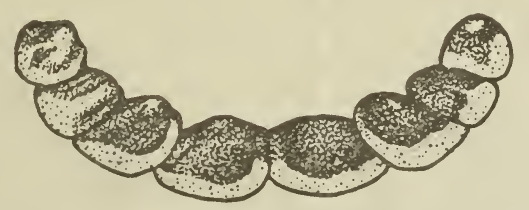

Fig. 1.-Internal face of incisors of the calf.

As the animal approaches 2 years of age the center pair of temporary incisor teeth or pinchers are replaced by the permanent pinchers which at 2 years attain full development.

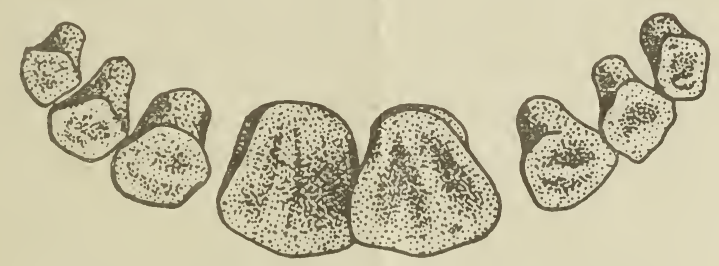

FIG. 2.-Internal face of incisors at 2 years.

At from $2 \frac{1}{2}$ to 3 years the permanent first intermediates are cut and are usually fully developed at 3 years.

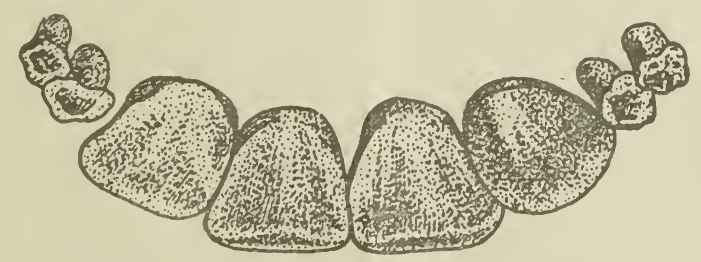

Fig. 3.-Internal face of incisors at 3 years. 
At $3 \frac{1}{2}$ years the second intermediates or laterals are cut. They are on a level with the first intermediates and begin to wear at 4 years.

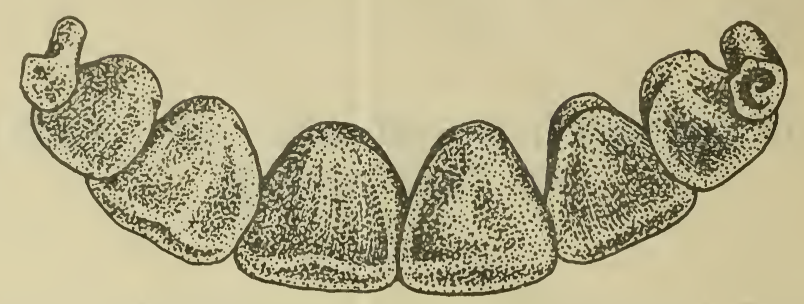

FIG. 4.-Internal face of incisors at 4 years.

At $4 \frac{1}{2}$ to 5 years the corner teeth are replaced, the animal at 5 years having the full complement of incisors with the corners fully developed.

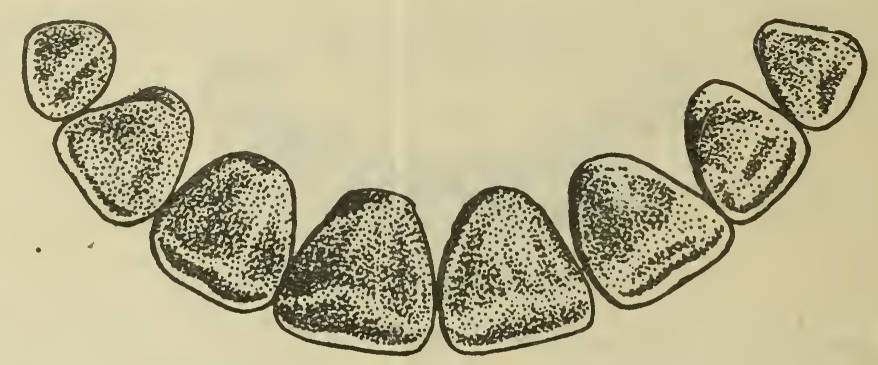

Fig. 5.- Internal face of incisors at 5 years.

At 5 to 6 years there is a leveling of the permanent pinchers, the pinchers usually being leveled at six and both pairs of intermediates partially leveled and the corner incisors showing wear.

From seven to eight the pinchers are noticeably worn; from eight to nine the middle pairs, and by ten years the corner teeth.

After 6 years the arch gradually loses its rounded contour and becomes nearly straight by the twelfth year. In the meantime the teeth have gradually become triangular in shape, distinctly separated, and show the progressive wearing to stubs.

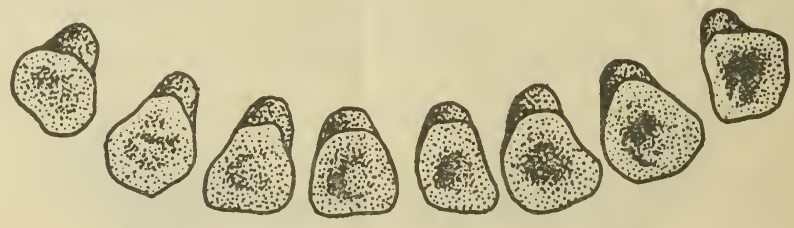

FIG. 6.-Internal face of incisors at 12 years. 
